\begin{tabular}{|c|c|c|}
\hline (j) & $\begin{array}{c}\text { Türkiye Tarımsal Araştırmalar Dergisi } \\
\text { dergipark.org.tr/tutad }\end{array}$ & $\begin{array}{l}\text { Turk J Agric Res } \\
\text { 2019, 6(2): 230-236 } \\
\text { @ TÜTAD } \\
\text { ISSN: 2148-2306 }\end{array}$ \\
\hline $\begin{array}{l}\text { UNIVERSiTESI } \\
\text { Bilimin Dsüumata }\end{array}$ & Derleme / Review & $\begin{array}{l}\text { e-ISSN: } 2528-858 X \\
\text { doi: } 10.19159 / \text { tutad.440783 }\end{array}$ \\
\hline
\end{tabular}

\title{
Vermikompost Üretim Tekniği ve Üretimde Kullanılan Materyaller
}

\author{
Mustafa CERITOĞLU ${ }^{1 *}$, Sezer ŞAHIN ${ }^{2}$, Murat ERMAN ${ }^{1}$ \\ ${ }^{1}$ Siirt Üniversitesi, Ziraat Fakültesi, Tarla Bitkileri Bölümü, Siirt, TÜRKIYYE \\ ${ }^{2}$ Gaziosmanpaşa Üniversitesi, Ziraat Fakültesi, Toprak Bilimi ve Bitki Besleme Bölümü, Tokat, TÜRKIYE
}

\begin{tabular}{|c|c|}
\hline Geliş Tarihi/Received: 04.07 .2018 & Kabul Tarihi/Accepted: 30.06 .2019 \\
\hline \multicolumn{2}{|c|}{ ORCID ID (Yazar surasina göre / by author order) } \\
\hline (1D) orcid.org/0000-0002-4138-4579 (1) orcid.org/0000-0003-3 & rcid.org/0000-0002-1435-1982 \\
\hline
\end{tabular}

Öz: Vermikompost, organik atıkların solucanların sindirim sisteminden geçirilmek suretiyle mezolifik kompostlama işlemine tabi tutularak elde edilen son üründür. Toprakta organik maddenin noksanlığı tarımsal üretimin verimliliğini azaltmakta ve sürekliliğine engel olmaktadır. Toprak organik maddesi mikrobiyal canlılığı artırmak, toprak yapısını düzeltmek, toprağın besin ve hormonal içeriğini düzenlemek suretiyle tarımsal üretkenliği artırmaya yardımcı olur. Bu nedenle tarım topraklarımızda vermikompost kullanımının teşvik edilmesi gerekmektedir. Vermikompost üretim tesisinin kurulması son derece kolay ve pratik bir işlemdir. Doğru şekilde kurulan bir tesis ile ticari anlamda başarıya ulaşmak mümkündür. Böylece hem sentetik gübre kullanımının azaltılması hem de yerli ekonomiye katkı sağlanması teşvik edilmiş olacaktır. Bu çalışmanın amacı vermikompost üretim yöntemleri ve kullanılan materyaller hakkında bilgilendirme yapmaktır.

Anahtar Kelimeler: Vermikompost, solucan gübresi, organik gübre, organik madde, bitki besleme, Eisenia fetida

\section{Vermicompost Production Technique and Materials Used in Production}

\begin{abstract}
Vermicompost is the final product obtained by subjecting organic wastes to mesolytic composting through the digestive system of worms. The shortage of organic matter in soil reduces the productivity of agricultural production and hampers its continuity. Soil organic matter helps to increase agricultural productivity by increasing microbial viability, improving soil structure, regulating nutrient and hormonal content of soil. For this reason, the use of vermicompost in agricultural lands should be encouraged. The installation of the vermicompost production facility is extremely easy and practical. It is possible to achieve commercial success with a properly installed facility. Thus, both the reduction of the use of synthetic fertilizers and the contribution to the domestic economy will be encouraged. The aim of this study is to give information about vermicompost production methods and materials.
\end{abstract}

Keywords: Vermicompost, earthworm manure, organic manure, organic matter, plant nutrition, Eisenia fetida

\section{Giriş}

Dünyadaki temel besin kaynaklarının büyük çoğunluğu tarımsal üretim ile elde edilmektedir. Bu sebeple tarihin ilk çağlarından günümüze kadar geçen sürede tarımsal ürünler insan beslenmesinde vazgeçilmez olmuştur. Dünyada 2016 y1lı kayıtlarına göre 7.5 milyar insan yaşamakta olup, bu rakamın 21. yüzyılın ortalarına doğru 9.5 milyar civarında olacağ ark., 2016). Artan dünya nüfusuna paralel olarak besin ihtiyacının da artacağı bilinen bir gerçektir. Bu nedenle, sürdürülebilir tarım sistemlerinin doğru ve modern tekniklerle uygulanması yeryüzündeki canlıların beslenmesi açısından büyük önem taşımaktadır.

İkinci dünya savaşı yıllarında "Yeşil Devrim", olarak adlandırılan ve inorganik (kimyasal) gübre ve ilaç kullanımı esasına dayanan hareket, hızlı 
ürün artışı sağlaması sebebiyle oldukça popülerlik kazanmıştır (Schuman ve Simpson, 1997). Ancak, yoğun olarak kullanılan kimyasal gübre ve ilaç kalıntılarının toprakta ve bitkilerde birikerek ve sızan sular ile yer altı kaynaklarına karışarak insan ve hayvan sağlığını tehdit ettiği ve kalıntıların mutajen, teratojen ve kansorejen etkilerinin ortaya çıktığı belirlenmiştir (Bailer-Anderson ve Anderson, 2000). Yoğun tarımsal kimyasalların kullanımının; tarım topraklarında da olumsuzluklara, toprak yapisinda bozulmalara ve toprağın verimsiz bir hal almasına sebep olduğu ifade edilmektedir (Chen ve ark., 2010). Son çeyrek asırda tarımsal anlamdaki bu gelişmeler, özellikle sürdürülebilir toprak verimliliğini olumsuz yönde etkilemiştir.

Günümüzde ise; toprağın yapısını iyileștirmeye ve verimliliğini korumaya yönelik olarak organik gübrelerin kimyasal gübreler ile kullanımını teşvik edildiği modern tarım sistemlerinin uygulanması ile birlikte toprak yönetimin sürdürülebilir hale getirilmesinde önemli aşamalar kaydedilmeye çalışılmaktadır. Bu amaçla yapılan uygulamalar arasında, toprağın organik madde ve besin elementi açısından zenginleşmesinde rol oynayan ve önemli organik gübrelerin başında yer alan vermikompost uygulamas1 gelmektedir (Huang ve ark., 2013; Emperor ve Kumar, 2015).

Öte yandan toprakta, canlılığın sağlanması ve korunmasi toprak mikroorganizmalarının faaliyetleri ile gerçekleşir. Mikrobiyal faaliyetlerin devamlılığ 1 için ise toprakta organik maddenin varlığına ihtiyaç duyulmaktadır. Mikroorganizmalar organik maddeyi parçalayarak besin ihtiyaçlarını karşılar ve bitkiler ayrışan minerallerden besin kaynağı olarak faydalanırlar. Hayvansal ve bitkisel kökenli organik atıklar toprağa karıştırılmadan önce yararlı bakterilerin popülasyonunu arttırmak ve zararlı mikroorganizmaları yok etmek amacıyla termolifik bir işlem olan fermantasyon (kompostlama) işlemine tabi tutulur (Pamir, 1985). Ancak son y1llarda termolifik kompostlama ürünlerinden hem besleyici içerik hem de organik materyal oranı olarak daha üstün olan vermikompost kullanımı hızla yaygınlaşmaktadır. Mezolifik kompostlama esasına dayanan vermikompost üretiminde ileri kompostlama işlemi solucanlara yaptırılmakta ve solucanların sindirim sisteminden geçen zengin içerikli bir son ürün elde edilmektedir (Fracchia ve ark., 2006; Domínguez ve Edwards, 2011a).

Vermikompost üretiminde yaygın olarak kullanılan materyaller büyükbaş hayvan gübresi, bitkisel atıklar, evsel atıklar ve endüstryel atıklardır. En yaygın olarak kullanılan materyal sığır gübresidir. Gerek temin edilmesinin kolay olması gerekse de birkaç gün içerisinde mama olacak forma dönüşebilmesi sığır gübresini ön plana çıkaran özelliklerdir. Mama olarak sadece fermente edilmiş sığır gübresi kullanılabileceği gibi, diğer organik atıklar ile karıştırılmış halde de kullanılabilir. Mama olarak kullanılacak organik materyallerde asitlik özelliğe sahip atıklardan kaçınılmalıdır. Ayrıca et, süt, soğan, sarımsak gibi kötü kokuya sebep olacak besinlerin de tercih edilmemesi gerekmektedir.

Vermikompost ürünlerinin bitki gelişiminden toprak düzenleyici etkilerine, antioksidan etkisinden her türlü (bitkisel, hayvansal, endüstriyel vs.) atıkların üretimde kullanılabilmesine kadar birçok avantajı bulunmaktadır. $\mathrm{Bu}$ çalışmanın amac1, vermikompost materyalinin genel özellikleri hakkında fikir vermek, üretimindeki tekniklerin ve kullanılan materyallerin anlaşılmasına yardımcı olmak, farklı koşullar için uygun metodolojinin uygulanmasına katkı sağlamaktır.

\section{Vermikompost Üretim Materyalleri ve Üretim Şekilleri}

\subsection{Vermikompost üretiminde kullanılan solucan türleri}

Vermikompost üretiminde Eisenia fetida (tiger worm), Eisenia andrei (red tiger worm), Dendrobaena veneta, Lumbricus rubellus (red worm), Perionyx excavatus (indian blue worm), Eudrilus eugeniae (African nightcrawler) türleri başlıca kullanılan solucan türleridir (Domínguez ve Edwards, 2011b).

Vermikompost üretimi yapılacak olan bölgenin iklimi ve hava şartları, solucan seçiminde önemli bir etkendir. Eisenia fetida, Eisenia andrei ve Dendrobaena veneta türleri 1lıman iklim kuşağında daha fazla görüldüğü için 1lıman iklim bölgesinde yapılacak vermikompost üretiminde kullanımı yerinde olacaktır. Lumbricus rubellus ve Perionyx excavatus türleri ise sıcak tropik iklim özelliği gösteren bölgelere daha iyi adapte olmaktadır (Şimşek Erşahin, 2007).

Ticari amaçlı yapılan üretim alanlarında en fazla tercih edilenler sirasi ile Esensia spp. (Bansal ve Kapoor, 2000) ve Lumbricus spp. (Dickerson, 2004) türleridir. Bu iki türü karşılaştırmak için yapılan bir çalışmada Eisenia fetida türünden elde edilen vermikompost ürününün toplam organik madde, $\mathrm{C}: \mathrm{N}$ oran1, toplam azot $(\mathrm{N})$, fosfor $(\mathrm{P})$, potasyum (K) miktarları bakımından daha üstün özellikler taşıdığı ifade edilmiştir. Ayrıca bu tür ile elde edilen vermikompost ürünlerinde tuzluluk oranının (Elektriksel iletkenlik, EC) daha düşük olduğu görülmüştür (Kaviraj, 2003). 
Yaygın olarak kullanılan bu türler "Kırmızı Kaliforniya Solucanı” olarak da bilinir. Sözü edilen türlere ait görüntüler Şekil 1 ve 2'de gösterilmiştir.

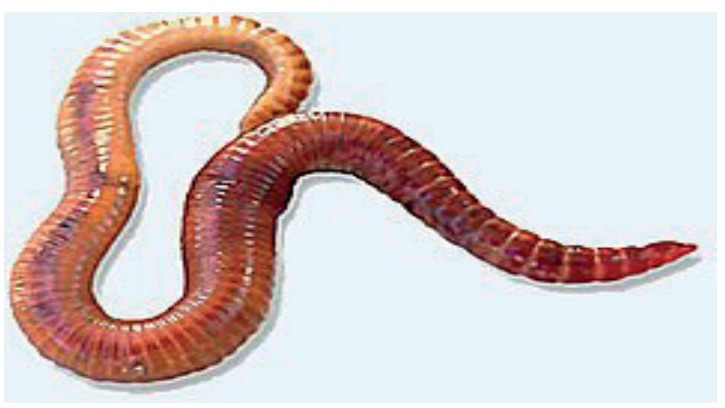

Şekil 1. Eisenia fetida türü

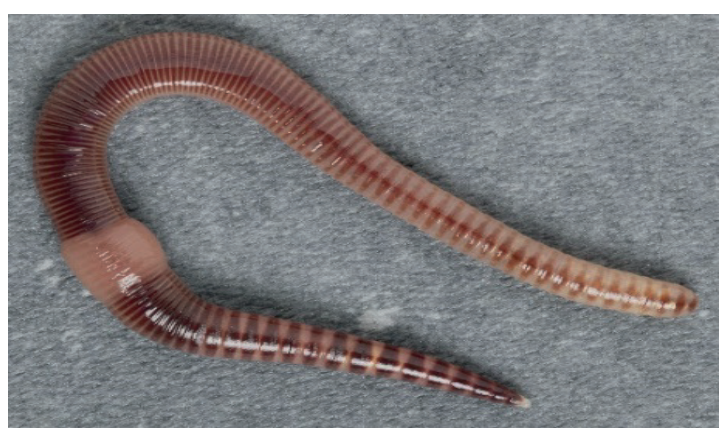

Şekil 2. Lumbricus rubellus türü

Eisensia fetida diğer türlere nazaran daha yüksek üreme potansiyeline sahiptir. Bu türün içerisinde bulunan solucanlar diğer solucan türlerinden daha hızlı besin tüketirler. Böylece daha hızlı gübre elde edilmesine olanak sağlarlar. Oldukça geniş bir adaptasyon yeteneğine sahip olmaları, çok farklı coğrafyalarda üretim yapılabilmesine imkân verir (Domínguez ve Edwards, 2011b). Neredeyse tüm dünyada ticari amaçlı üretim yapmak isteyen üreticilerin özellikle 1lıman iklim bölgeleri başta olmak üzere Eisensia fetida tercih etmeleri, hem elde edilen ürünün daha kaliteli olmasının hem de türün yüksek adaptasyon yeteneğinin bir sonucudur (Edwards ve Bohlen, 1996).

\subsection{Vermikompost üretim tekniği}

Vermikompost ürünü elde etmek için kullanılan organik materyallerin her birisinin hazırlanma süresi ve tabi tutuldukları işlemler farklılık göstermektedir. Vermikompost üretiminde kullanılan organik atığın cinsi elde edilecek ürünün kalitesinde farklı sonuçlar ortaya koymaktadır (K1zılkaya ve Turkay, 2014; Aynehband ve ark., 2017). Büyük baş hayvan gübreleri veya domuz gübresi kullanılacağı zaman, saman ile karıştırılır veya üre seviyesinin düşürülmesi amacıyla sıv1 kısımdan arındırılarak kullanılır. Domuz gübresi en erken 2 hafta gibi bir sürede kullanılabilecek uygunluğa gelirken, sığır gübresi 3-5 gün içerisinde kullanılabilir. Kompostun en uygun düzeyde fermente olabilmesi için gereken optimum süre 9 gündür (Nair ve ark., 2006). Bu süre termolifik parçalanma ve zararlı patojenlerin yok olması için yeterlidir (Bansal ve Kapoor, 2000).

Kanatlı hayvanların gübreleri vermikompost üretimine elverişli olmadığı için tercih edilmez. Bunun başlıca sebebi kanatlı hayvan gübrelerinde (tavuk, hindi, ördek, güvercin vs.) yüksek düzeyde amonyak bulunur ki, amonyak solucanlarda zehir etkisi yapar (Tchobanoglous ve ark., 1993). Bunun dışında endüstriyel atıklar, kâğıt, şeker ve bira sanayii atıkları, belediye ve kanalizasyon atıkları, restoran ve bahçe atıkları vermikompost üretimi için substrat materyal olarak kullanılabilmektedir (Edwards, 1995).

Vermikompost üretiminde en önemli aşamalardan birisi solucanlara verilecek olan mamanın doğru şekilde hazırlanmasıdır. Hazırlanacak olan mamanın fermantasyona tabi tutulması gerekir. Fermantasyon işlemi kısaca organik materyalin ayrışmasını sağlamaktır. Kompostun hazırlanmasi ve mama olarak verilmesinde en önemli hususlardan birisi nem içeriğidir. Mikroorganizmaların Faaliyet gösterebilmeleri için mutlaka neme ihtiyaç vardır. Nem içeriği \% 40'ın altına düşerse mikrobiyal faaliyetler minimum seviyeye inmekte ve \% 10 'un altına düşerse tamamen durmaktadır (Tchobanoglous ve ark., 1993). Bakteriler için en uygun nem oranı \% 55 olmasının yanında, solucanlar optimum düzeyde besin ortamı için biraz daha fazla neme (\% $\%$ 65-75) ihtiyaç duyarlar (Rostami ve ark., 2010). Gelişmiş sistemlerde nem durumunu gösteren cihazlar bulunmaktadır. İlkel yöntemlerle nem kontrolünün yapılmasında ise mamanın avuç içinde sıkıldığında yapışacak ama su çıkmayacak derecede nemli olması esas alınmaktadır.

Vermikompost üretiminde ortam sıcaklığ kontrol altında tutulmalıdır. Sicaklık derecesi hem bakterilerin hem de solucanların yaşamsal faaliyetleri için oldukça önemlidir. Solucanlar açık kan dolaşımına (soğukkanlı canlılar) sahip oldukları için vücut 1sıları çevre sıcaklığından doğrudan etkilenir (Misırlığlu, 2017). Eisenia fetida türü diğer türlere nazaran daha yüksek adaptasyon yeteneğine sahip olmasına rağmen, bulundukları havuz sıcaklığ $\quad 0 \quad{ }^{\circ} \mathrm{C}$ ve altına düşerse ölümler görülmektedir. Ortalama $7-8{ }^{\circ} \mathrm{C}$ civarında ise hayatta kalabiller, ancak faaliyet gösterme yetenekleri oldukça kısıtlanır. Türlere göre farklılık göstermesine rağmen genel olarak gelişimleri ve faaliyetleri için optimum ortam sicaklık $15-25{ }^{\circ} \mathrm{C}$ aralığındadır. Mikrobiyal faaliyetlerin optimum 
seviyede devam edebilmesi ve organik maddenin parçalanma hızının en üst seviyede olabilmesi için ise en uygun sıcaklık aralığı 15-30 ${ }^{\circ} \mathrm{C}$ 'dir (Rostami ve ark., 2009).

Kompost haline getirilmek üzere seçilen substrat materyalin $\mathrm{C}: \mathrm{N}$ oranı oldukça önemlidir. Yüksek C:N oranı mikrobiyal faaliyetlerin azalmasina sebep olur (Ökmen ve Algur, 2000). Çok düşük C:N oranına sahip materyallerde ise fazla miktarda bulunan amonyak solucanlar için toksik etki göstermektedir (Tchobanoglous ve ark., 1993). Bu nedenle seçilecek olan substrat materyalin belirlenmesi konusunda dikkatli davranılması gerekir.

Ticari amaçlı üretim yapılan büyük işletmelerde mama ihtiyacı yüksek miktarlarda olacağı için mamanın hazırlanmasında iş makinalarından yararlanılmaktadır. Sadece hayvan gübresi kullanılabileceği gibi bitkisel materyaller, evsel organik atıklar, endüstri atıkları gibi materyaller de karıştırılabilir. Yığın haline getirilen organik materyaller birkaç gün bekletilerek alt üst edilir. Yığının ihtiyaç duyulduğu oranda nem ihtiyacının da karşılanması gerekmektedir. Daha küçük işletmelerde veya kendi gübresini üretme amacı güden üreticilerin üretim alanlarında ise daha az ölçekli organik materyal kürek yardımı ile karıştırılmalıdır.

Vermikompost üretiminde birçok farklı yöntem kullanılmaktadır. Sınıflandırılacak olursa genel olarak yığınlar halinde veya kapalı kutu sistemlerde üretim yapılabilmektedir. Üretim yapılacak tesisin kurulumunda başlangıç maliyeti, üretim amacı, iş gücü veya mekanizasyon tercihleri etkili olan faktörlerdir.
Açık alanda toprak yüzeyinde sıra yığınlar halinde yapılacak bir üretimde iş gücü fazla olmamak ile birlikte ilk kurulum maliyeti de düşük olur. Ancak burada asıl dikkat edilmesi gereken hava sicaklığının düşük olduğu yerlerde bir şekilde yığın soğuktan korunmalı ve izole edilmelidir. Üretim açık alanda olduğu için sterilizasyonu da düşük olabilir ve yığına istenmeyen böcek veya organizma karıșabilir. $\mathrm{Bu}$ durumda üretilen vermikompostun kimyasal kompozisyonu değişmekte ve kontaminasyon sebebiyle ürün kalitesi düşmektedir.

Vermikompost üretim tesislerinin planlanmasında en önemli etkenlerden birisi kurulum maliyetidir. Düşük maliyet ile kurulması hedeflenen işletmelerde açık alana kurulmuş sıralar ve basit duvarlar ile çevrilmiş yataklar şeklinde tesisler kurulabilir. Siraların uzunluklarının bir sınırı olmamakla birlikte genişliği 2 metreyi geçmemelidir. Fazla geniş yapılacak sıralarda homojen ve düzgün işçilik imkânları kısıtlanmaktadır. Vermikompost karışımı doğrudan yatak üzerine serilir. Fazla sulama yapılırsa doğrudan zemin üzerinde olduğu için akıp gideceği için sorun olmayacaktır. En ilkel ve masrafsız üretim şekli olmakla birlikte diğer yöntemlere göre üretim daha yavaş gerçekleşir. $\mathrm{Bu}$ üretim yönteminin bir dezavantajı ise sıcak havalarda buharlaşma veya nemlendirmede sızıntı ile besin elementi kaybı gerçekleşebilir (Edwards, 1995). Açık alana kurulmuş sıralar metodu ile vermikompost üretimi yapılan bir tesisin görüntüsü Şekil 3'te gösterilmiştir.

Vermikompost üretim alanlarında işlem etkinliğini artırmak amacı ile kullanılan basit

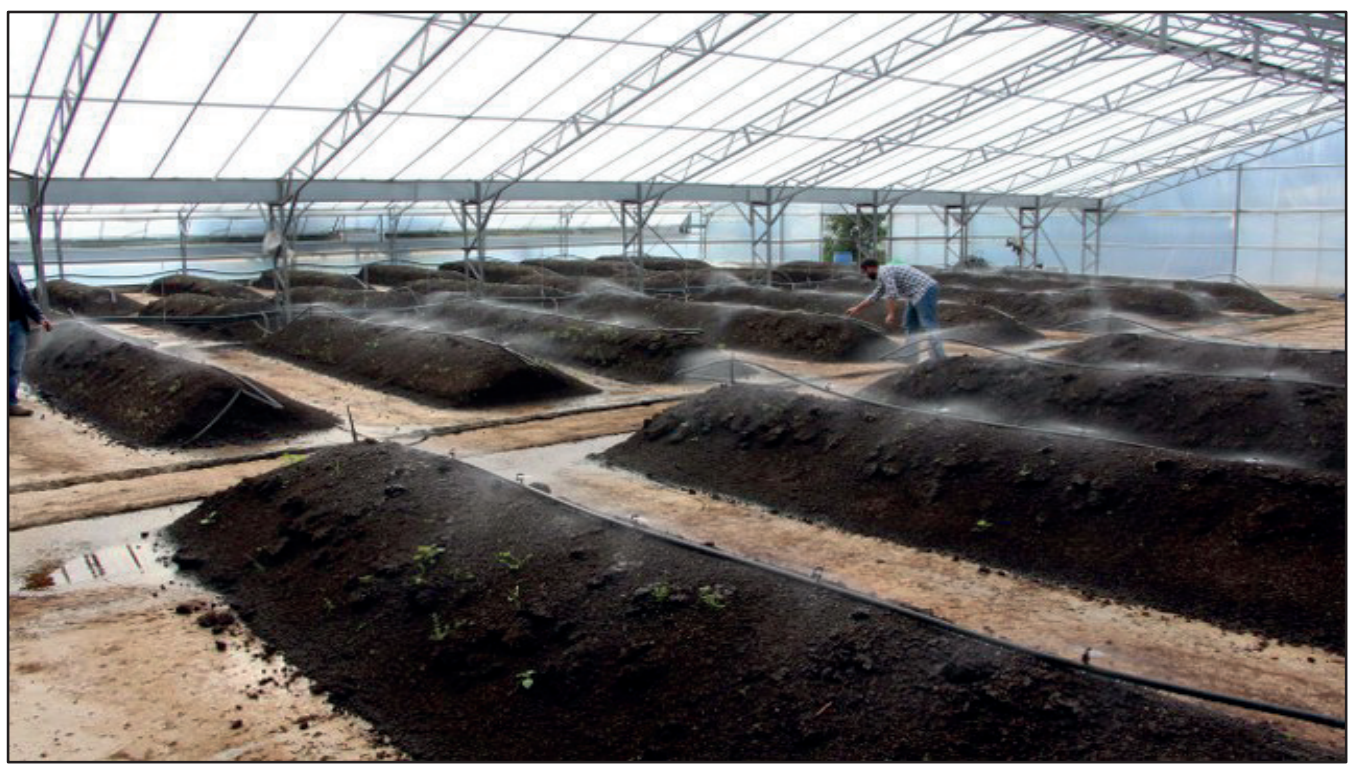

Şekil 3. Açık alana kurulmuş sıralar metodu ile vermikompost üretimi (Anonim, 2018a) 
yöntemin adı "hareketli kapaklı yataklar"dır (Şimşek Erşahin, 2007). Bu yöntemde organik materyal yüzeye 1-2 cm gibi ince tabakalar halinde verilir ve sistem hareketli bir kapak ile yanlardan yükseltilerek desteklenir. Solucanlar sürekli taze besinlerle beslenir ve yı̆̆ının içerisinde tüketilmeden kalan organik madde oranı en aza indirilmiş olur.

Büyük konteyner veya kutularda da vermikompost üretimi yapılmasına rağmen bu sistemlerin iş gücü yüksektir. $\mathrm{Bu}$ nedenle bu sistemler genelde ticari amaçla üretim için pek tercih edilmez. Ancak motor ve makara sistemleri ile donatılarak geliştirilmiş sistemlere olan talep gün geçtikçe artmaktadır. Sürekli akış sistemi adı verilen bu sistemlerde de diğer yöntemlerde olduğu gibi solucanlar üstten organik madde verilerek beslenir. Sistemin altında makaraya bağlı bıçaklar bulunur. Yukarıdan organik madde ilave edildikçe solucanlar üst tarafa akın eder ve alt tabakadan kesme gerçekleştirilir (Edwards, 1995). Hem zaman kaybı olmadan üretim yapılır hem de solucanlara müdahale edilmemiş olur. Solucanlar dışarıdan gelen en küçük müdahaleler ile strese girer ve kendilerini güvende hissedene kadar pasif halde beklemede kalırlar. $\mathrm{Bu}$ durumda solucanlar beslenmedikleri için gübre üretimi gerçekleşmez. Böylece üretim hızında azalmalara neden olur. Bahsedilen sebeplerden dolayı mümkün olduğunca solucanların yaşam alanlarına müdahale edilmemesi gerekmektedir. Sürekli akış sistemlerinde hiç sisteme müdahale etmeden sadece mama verilerek 2 y1l boyunca seri üretim yapılabilmektedir. Sürekli akış sistemlerinin kullanıldığ1 bir vermikompost üretim tesisinin görüntüsü Şekil 4'te gösterilmiştir.
Vermikompost materyalinin kalitesini etkileyen en önemli faktörlerden birisi de kurutma aşamasıdır. Üretilen vermikompostun özelliklerini kaybetmemesi için doğru şekilde kurutulması gerekmektedir. Vermikompost ürününün çiğ halinin doğru metodoloji ile kurutulmuş haline oranla toplam azot oranının \% 31.25 oranında daha düşük olduğu belirtilmektedir. Ayrıca Fosfor ve Potasyum oranlarının da sirası ile \% 63.75 ve \% 72.86 oranında düştüğü belirtilmektedir (Manyuchi ve ark., 2013). Vermikompostun doğrudan güneş görmeyen ve havalandırması bulunan bir ortamda kurutulması en doğru kurutma şeklidir. Kurutulacak ortamın havalandırma sorunu varsa ortamın nemli olmasından dolayı süreç uzun zaman alacaktır. Kurutma ortam sicaklığının 35 ${ }^{\circ} \mathrm{C}$ 'den fazla olmamas 1 tavsiye edilmektedir. Ayrica kurutma işlemi sonunda vermikompost materyalinin nem oranı için optimum değer \% 5055 'tir. Nem oranı \% 45 'in altına düşerse materyal siyah görünümünü kaybeder, tozlu ve gri bir görünüme kavuşur. Tekrar nemlendirmek siyah rengin tekrar gelmesini sağlamaz. Bu durum, materyalin mikrobiyal aktivitesindeki azalmanın da bir göstergesidir (Kakitis ve ark., 2017). Kurutma esnasında hastalık, zararlı, böcek vs. gibi bulaşıklardan izole edilmiş bir ortam tercih edilmelidir. Elde edilen ürünün pazar değerinin yüksek olabilmesi ve talep görmesi için dikkat edilmesi gereken bazı unsurlar mevcuttur. Öncelikle elde edilen ürün homojen ve yabancı maddelerden arındırılmış olmalıdır. Bu sebeple büyük işletmelerde mekanizasyon ile küçük işletmelerde ise daha ilkel araçlar veya yöntemler ile son ürünün elekten geçirilmesi gerekir.

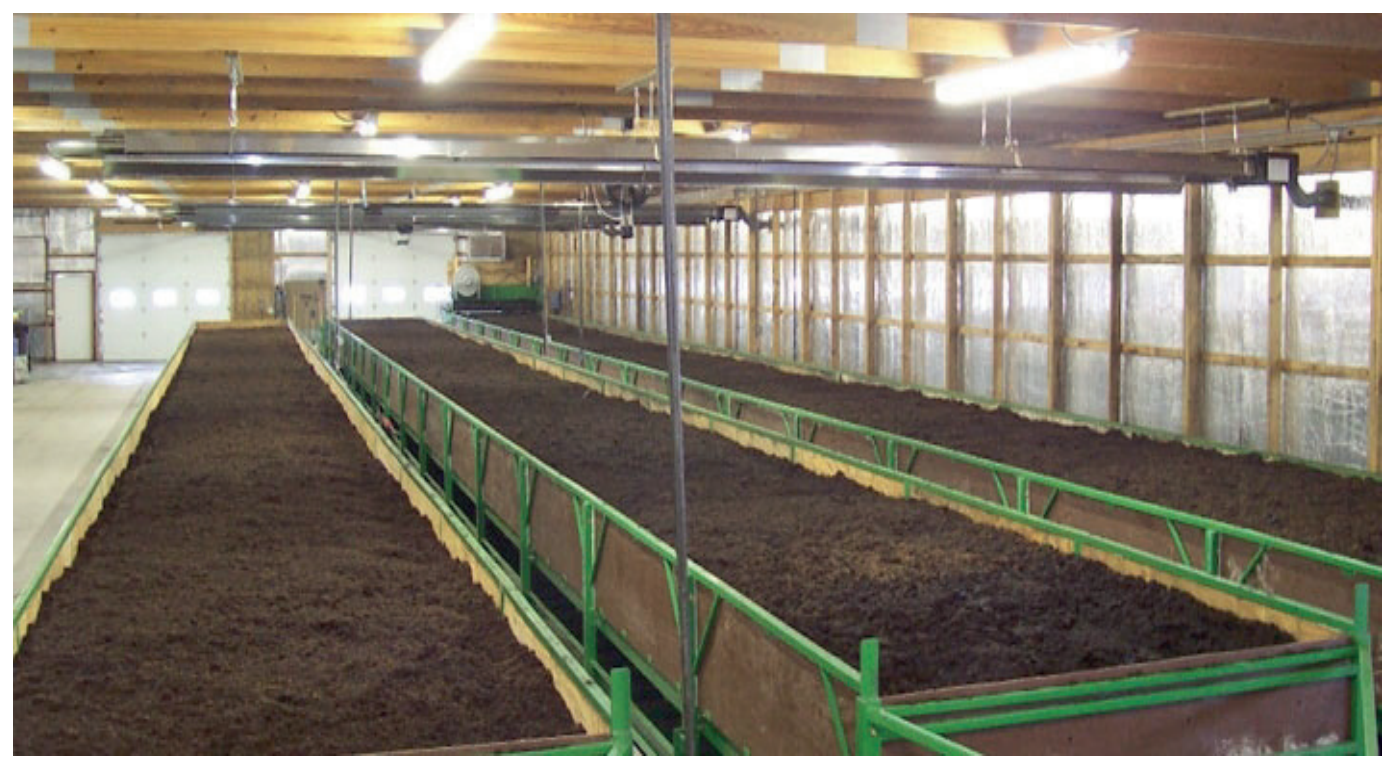

Şekil 4. Sürekli akış sistemlerinin kullanıldığı vermikompost üretim tesisi (Anonim, 2018b) 
Sterilizasyon imkanı olan gelişmiş üretim tesislerinde sterilize edilme işleminden hemen sonra vermikompost ürünü paketleme alanına sevk edilmektedir. Ticari amaçla üretimi yapılan vermikompost ürünlerinin özelliklerini koruması, yabancı madde bulaşığının engellenmesi, böcek ve zararlı mikroorganizmalarca tahrip edilmesinin önlenebilmesi için mutlaka ambalajlanarak bekletilmesi gerekmektedir. Eğer böyle bir imkân söz konusu değilse depo edilmek üzere hastalı, zararlı bakteriler, böcekler gibi etmenlerden arındırılmış bir ortam tercih edilmelidir. Açık bir alanda bekletilen organik materyaller zararlı mikroorganizmaların ve böceklerin yaşam alanı haline gelir.

\section{Sonuçlar}

Yapılan zirai çalışmaların tamamı doğrudan veya dolaylı olarak tarımsal üretime katkıda bulunmak ve sürekliliği sağlamak amacıyla yapılmaktadır. Ürün kalitesinin artırılması, verim artışının sağlanabilmesi ve bitki korumaya yönelik yoğun kimyasal madde kullanımı tarım topraklarının yapısının bozulmasına sebep olmaktadır. Tarımsal üretimde sürekliliğin sağlanabilmesi için toprak organik maddesinin korunması ve artırılması hayati önem taşımaktadır. Yapılan çalışmalar organik maddenin artırılması ve toprak yapısının düzeltilmesi yönünden vermikompost kullanımının etkili sonuçlar ortaya koyduğunu göstermektedir. Vermikompost kullanımı toprak organik maddesini arttırmanın dışında; toprağa bitki besin elementleri, hormonlar, enzimler ve humik maddeler kazandırmaktadır. Ayrıca mikrobiyal aktiviteyi artırarak toprak verimliliğini ve canlılığını olumlu yönde etkilemektedir.

Vermikompost kullanımını artırmanın birincil yolu çiftçilerin vermikompost kullanımına teşvik edilmesi ve artan talep karşısında vermikompost üretiminin artırılmasıdır. Üretim tesislerinin artması hem yerli ekonominin canlanmasına hem de organik atık sonununun çözülmesine katk1 sağlayacaktır. Ancak, kurulacak tesislerin uygun koşullarda ve doğru yöntemlerle faaliyete geçirilmesi ve elde edilen materyalin doğru işlemlere tabi tutulması elde edilen ürünün kalitesi açısından son derece önemlidir. Yeni girişimcilerin ve bilhassa tarım ile ilgilenen insanların vermikompost üretimi hakkında bilgilendirilmesi gerekmektedir. Aksi halde, düşük kaliteli bir ürün elde edileceği için elde edilen vermikompost materyalinden hedeflenen sonuçlar alınamaz. Bu durumdan hem üreticiler hem de materyali kullanan çiftçiler olumsuz yönde etkilenir.

\section{Kaynaklar}

Abhilash, P.C., Tripathi, V., Edrisi, S.A., Dubey, R.K., Bakshi, M., Dubey, P.K., Ebbs, S.D., 2016. Sustainability of crop production from polluted lands. Energy, Ecology and Environment, 1(1): 54-65.

Anonim, 2018a. Açık Alana Kurulmuş Sıralar Metodu İle Vermikompost Üretimi. (http://akmesolidem.com/), (Erişim tarihi: 12.09.2018).

Anonim, 2018b. Sürekli Akış Sistemlerinin Kullanıldı̆̆ Vermikompost Üretim Tesisi. (https://www.ekosol. net/), (Erişim tarihi: 10.01.2018).

Aynehband, A., Gorooei, A., Moezzi, A.A., 2017. Vermicompost: An eco-friendly technology for crop residue management in organic agriculture. 4th International Conference on Power and Energy Systems Engineering, September 19-21, CPESE, Berlin, pp 25-29.

Bailer-Anderson, C., Anderson, R.S., 2000. The effects of chlorothalonil on oyster hemocyte activation: Phagocytosis, reduced pyridine nucleotides, and reactive oxygen species production. Environmental Research, 83(1): 72-78.

Bansal, S., Kapoor, K.K., 2000. Vermicomposting of crop residues and cattle dung with Eisenia foetida. Bioresource Technology, 73(2): 95-98.

Chen, G., Zheng, Z., Yang, S., Fang, C., Zou, X., Luo, Y., 2010. Experimental co-digestion of corn stalk and vermicompost to improve biogas production. Waste Management, 30(10): 1834-1840.

Dickerson, G.W., 2004. Vermicomposting Cooperative extension service college of agriculture and home earthworms and waste management. The Waste Management, 30(10): 1834-1840.

Domínguez, j., Edwards, C.A., 2011a. Vermiculture technology: Earthworms, Organic Waste and Environmental Management: In: Clive A. Edwards, Norman Q. Arancon, Rhonda L. Sherman (Eds.), Biology and Ecology of Earthworms Species used for Vermicomposting, 2nd edn., CRC Press. Boca Raton, Florida. pp 25-37.

Domínguez, J., Edwards, C.A., 2011b. Vermiculture Technology: Earthworms, Organic Waste and Environmental Management: In: Sherman (Eds), Relationships between composting and vermicomposting: relative values of the products, 2 nd edn., CRC Press. Boca Raton, Florida, pp 1-14.

Edwards, C.A., 1995. Commercial and environmental potential of vermicomposting. BioCycle, 62-63.

Edwards, C.A., Bohlen, P.J., 1996. Biology of earthworms. In: P.J. Bohlen and C.A. Edwards (Eds.), Biology and ecology of earthworms, 3rd Edn., Hall, New York, pp 426.

Emperor, G.N., Kumar, K., 2015. Microbial population and activity on vermicompost of "Eudrilus eugeniae" and "Eisenia fetida" in different concentrations of tea waste with cow dung and kitchen waste mixture. International Journal of Current Microbiology and AppliedSciences, 4(10): 496-507. 
Fracchia, L., Dohrmann, A.B., Martinotti, M.G. and Tebbe, C.C., 2006. Bacterial diversity in a finished compost and vermicompost: differences revealed by cultivation independent analyses of PCR-amplified 16S rRNA genes. Applied Microbiology and Biotechnology, 71(6): 942-952.

Huang, K., Li, F., Wei, Y., Chen, X. and Fu, X., 2013. Changes of bacterial and fungal community compositions during vermicomposting of vegetable wastes by "Eisenia foetida". Bioresource Technology, 150: 235-241.

Kalkitis, A., Nulle, I., Vronskis, O., 2017. Experimental study of vermicompost drying process. $16^{\text {th }}$ International Scientific Conference Engineering for Rural Development, May 26, Jelgava, Latvia, pp 1086-1092.

Kaviraj, S.S., 2003. Municipal solid waste management through vermicomposting emplojing exotic and local species of earthworms. Science Direct, 90(2): 169173.

Kizılkaya, R., Turkay, F.S.H, 2014. Vermicomposting of Anaerobically Digested Sewage Sludge with Hazelnut Husk and Cow Manure by Earthworm Eisenia foetida. Compost Science and Utilization, 22(2): 68-82.

Manyuchi, M.M., Phiri, A., Muredzi, N., Chirinda, N., 2013. Effect of Drying on vermicompost macronutrient composting. International Journal of Inventive Engineering and Science, 1(10): 1-3.

Misırlığlu, M., 2017. Toprak Solucanları-Biyolojileri, Ekolojileri ve Türkiye Türleri. Nobel Yayınları
(2. Baskı). Nobel Yayıncılık, Yayın No: 1860, Teknik Yayın No: 141, Ankara.

Nair, J., Sekiozoic, V., Anda, M., 2006. Effect of precomposting on vermicomposting of kitchen waste. Bioresource Technology, 97(16): 2091-2095.

Ökmen, G., Algur, Ö.F., 2000. Farkl1 karbon kaynaklarının ve $\mathrm{C} / \mathrm{N}$ oranlarının mikrobiyal denitrifikasyon üzerine etkileri. Turkish Journal and Biology, 24(3): 533-542.

Pamir, M.H., 1985. Fermantasyon Mikrobiyolojisi. Ankara Üniversitesi Yayınları, Genel Yayın No: 936, Teknik Yayın No: 267, Ankara.

Rostami, R., Nabaei, A., Eslami, A., 2009a. Survey of optimal temperature and moisture for worms' growth and operating vermicompost production of food wastes. Health and environment, 1(2): 105-112.

Rostami, R., Nabaei, A., Eslami, A., Najafi Saleh, H., 2010a. Survey of optimal conditions for worm's growth and vermicompost production of prepared food wastes. Ofoghe-Danesh, 15(4): 76-84.

Schuman, S.H., Simpson W.M., 1997. A clinical historical overview of pesticide health issues. State of the Art Reviews: Occupational Medicine, 12(2): 203207.

Şimşek Erşahin, Y., 2007. Vermikompost ürünlerinin eldesi ve tarımsal üretimde kullanım alternatifleri. Gaziosmanpaşa Üniversitesi Ziraat Fakültesi Dergisi, 24(2): 99-107.

Tchobanoglous, G., Theisen, H., Vigil, S.A., 1993. Integrated Solid Waste Management, Engineering Principle and Management Issue. McGraw Hill Inc, New York. 